\title{
NEGOTIATING ELUSIVE JUSTICE: DILEMMAS OF LAND DISTRIBUTION IN SOUTHERN AFRICA
}

\author{
Mark Anstey \\ $B A(S W)$ MA(SW) Adv Dipl IPM D Phil \\ Professor Emeritus, Nelson Mandela University
}

\section{SUMMARY}

Transitions to democracy across southern Africa have been difficult and inevitably flawed. Shifts in international values, national demographics and power realities see social conflicts mutate through time, making societal transformation not a point of arrival, but an ongoing process. In Zimbabwe, and more recently Namibia and South Africa, land ownership and control have become bitterly contested issues. If one accepts that injustices were perpetrated in the past, what principles should guide their remedy? This article considers the complexities arising from competing conceptions of justice over land ownership and management in the context of changing political pressures and dilemmas as to who land might be taken from, along with future dilemmas about equitable distribution and productive management. If the crisis-driven experience of Zimbabwe is to be averted, stakeholders in Namibia and South Africa must find jointly acceptable principles to guide action into the future, and it is likely that no single principle of justice will suffice - a principled multi-track approach based on a mix of utilitarian, restorative and economic empowerment logics must be negotiated ... and then urgently implemented.

\section{$1 \quad$ INTRODUCTION}

The popular injunction "no peace without justice" negates the reality that many violent conflicts are rooted in competing ideologies of justice, and in the evolution of such ideologies within societies through time. Despite commonalities in the mythologies and narratives across cultures through history, ${ }^{1}$ a confluence of identities has not emerged. During the twentieth century, powerful shifts occurred in international values as occupational imperialism gave way to an era of nation states founded on principles of sovereignty and self-determination. The United Nations was established as a vehicle of international cooperation, conflict prevention and regulation in a fast-changing world. Modern international institutions have facilitated progress in preventing deadly conflict between nations, ${ }^{2}$ and although we live in the least violent time in history, ${ }^{3}$ divisions with high potential for

Campbell The Hero with a Thousand Faces 3ed (2008).

Zartman Preventing Deadly Conflict (2015).

Pinker The Better Angels of Our Nature: The Decline of Violence in History and its Causes (2011); Morris War. What Is It Good For? (2014). 
violence still exist. Some are a carry-over from conflicts only partially resolved in a previous time. The current shape of the global economy, and who dominates it, has a past not only of differential technological and commercial development but also of violent acquisition and repression. While the injustices of imperial acquisition and exploitation may be commonly acknowledged, remedial responses have sometimes proved elusive for people living in colonies of the past.

One problem is that remedies are being sought in a values environment very different from that in which the problems originated. White colonialists arrived with superior arms, farming technologies, systems of government and administration, and a sense of entitlement to land they saw as neither owned nor optimally used. Having taken over a territory, these were used, as with all imperial systems, to achieve dominance and stability, and to extract rewards primarily for their own identity group. Rather than narrowing, gaps in skills and living standards between colonisers and indigenous people widened. For instance, ownership of the land across southern Africa enabled white farmers to evolve competencies and accumulate capital through access to resources denied indigenous people through repressive laws. This has played out in failed land-transfer projects, apart from problems arising from poor governance, corruption and a lack of institutionalised support for new farmers. Competing perceptions of justice have made for complex transitions to majority rule in southern Africa. Democracies based in the first instance on the negotiation of primary rights become threatened if not accompanied by significant improvements in material well-being (secondary rights) ${ }^{4}$ and if the potential of negotiation to manage the divisions generated for and by governments in these scarce-resource societies is not fulfilled.

\section{IMPERIAL VALUES}

Under the banner of Christian civilisation, European nations launched an aggressive international campaign of acquisition from the late 1400s, enslaving millions, looting goods and taking land across the Americas, Africa and Asia. Local populations did not have the technology, weaponry or immunity to disease necessary to mount much of a resistance. ${ }^{5}$ Religious leaders and philosophers sanctioned the imperial takeover of lands, especially if they were populated by peoples seen as primitive and who were not making "appropriate" use of it, and were in any event seen to be "born to slavery". Armstrong ${ }^{6}$ points to the likes of Hobbes, Locke and Donne supporting the logic that the failure of indigenous peoples to develop the lands in which they lived deprived them of any legal claim to its ownership.

Anxious not to go to war among themselves over the continent, European powers distributed Africa among themselves at the Berlin Conference in 1884 with little regard for the rights of indigenous peoples. A similar process occurred in the creation of the modern Middle East in the Sykes-Picot Agreement (1917) and the Cairo Conference (1921). Mixed in with

Collier Wars, Guns and Votes (2009).

Diamond Guns, Germs, and Steel (2005); Armstrong Fields of Blood: Religion and the History of Violence (2014) 220237.

$6 \quad$ Armstrong Fields of Blood 220237. 
perceptions of civilisational and racial superiority, white settlers brought with them the concept of land ownership. However, the logic of African empires in pre-colonial times was founded in control over peoples rather than territory. ${ }^{7}$ Pre-colonial farming was largely of a subsistence nature and people moved on once an area of land had been used. Negotiations over land, where they occurred, were thus deeply flawed, founded in different understandings of land use and conducted in a context of asymmetric power and literacy.

Particularly in southern Africa, European nations sought not simply to extract mineral wealth but encouraged their own people to settle, and to assume governance of territories they had created. Imbued with a deep sense of civilisational superiority and imperial loyalty, colonists took the land because they could. Imperial rule in Africa for the most part lasted only about 70 years - and it did not involve large military occupation, but its impact was huge. In 1939, the British used only 1233 administrators and 938 police to control 43 million people in tropical Africa; the French, about 4500 to govern 18 million in French West Africa; and the Belgians, about 2400 in the Congo. ${ }^{8}$ Expenditure was largely directed at development for extraction of mining and agricultural resources. The technological capacity of European colonisers enabled them quite quickly to open up mining and agricultural economies, create transport, energy and water infrastructures, and establish commercial, industrial and service sectors. This was not without extraordinary vision, courage, effort or investment of energy on the part of settlers, but also involved repression, exploitation and dispossession. Superiority in arms also enabled settlers to assume a Leviathan role in the region; British colonial forces brought under control rebellious Shonas and Matabeles (warring also among themselves) in Rhodesia, as well as the Boers, the Zulus and the Xhosas in South Africa. After the defeat of Germany in World War I, South Africa took control of South West Africa.

In all three countries under consideration here, white minority governments promulgated laws controlling land possession on the basis of race. South Africa passed Land Acts in 1913 and 1936 effectively limiting land ownership of the black population to just 13 per cent of its land area; Rhodesia passed the Land Tenure Act (1969) limiting black people to ownership of just over 50 per cent of the land; and South West Africa (under the control of South Africa after World War I) set limits at under 40 per cent.

\section{THE POST-WORLD-WAR-II SHIFT IN VALUES}

After World War II, Western empires did not give way to new empires but, for the first time, to an era of nation states founded on principles of sovereignty and self-determination. In Western societies, human-rights values and secular humanism supplanted the values of imperialism; at the same time, the West embraced an ideology founded on free markets and rights of property ownership as core to values of freedom and economic growth. Across Africa, movements for decolonisation emerged, ${ }^{9}$ commonly reflecting

Herbst States and Power in Africa (2000) 35-57.

Herbst States and Power in Africa 78.

Jansen and Osterhammel Decolonization: A Short History (2017); Fanon The Wretched of the Earth (1963); Mbeki I Am An African Statement in Konrad Adenauer Stiftung Occasional 
a demand for dignity, a return of political power, and ownership and control of national resources.

Across southern African countries, white settler communities, which had invested their energies and capital in national development (albeit for selfish ends), remained imbued with the ideologies of imperialism and racial superiority decades longer than the empires that had sent them there. When the imperial tide went out after World War II, they found themselves stranded, seeing themselves betrayed both by their mother populations (from whom they wanted independence anyway) and facing insurrection from the indigenous people they continued to dominate. In short, they lost fit with a fast-changing international political environment. Events following independence in countries to the north embedded fears of loss of political control and severe economic loss in nations they saw themselves as having literally "carved out of the bush". But international support for their cause disappeared and shifted instead to indigenous national liberation movements, which stepped up pressure for democratic revolutions inspired often by the ideologies of Marx and Lenin, Mao, Fanon, black consciousness and African communalism. In the context of the Cold War, white governments found some confused support from the West - to the extent that communism was the declared enemy.

The resistance of white settler communities in Zimbabwe, Namibia and South Africa made for later, more difficult and violent processes of freedom and independence than enjoyed in other African countries. Despite divergent routes, all eventually arrived at negotiated constitutional arrangements based on full political participation and protection of human rights, but which directly and indirectly protected the economic interests and earlier land acquisition of white settler communities. These arrangements were concluded partly in a spirit of reconciliation, but also because of a perceived immediate need among leaders of opposition groups to retain white skills, and to avert a haemorrhage of capital - in short, pragmatism. Transformative economic policy was left to the national liberation movements that achieved power through election to government. And unresolved issues on this front continue to threaten political and economic stability across the region.

\section{UNRESOLVED ISSUES OF LAND AND WEALTH}

Post-liberation populations across southern Africa have soared, but economic growth has not. In South Africa, slow economic growth over decades has stalled progress in black economic advancement. Economic realities coupled with modern approaches to the transformation of work have seen slow job creation and dented hopes that rafts of affirmative-action and black-economic-empowerment legislation might see both rapid transfers of wealth and demographic transformation of workforces. While the public sectors across southern Africa are now demographically representative, and provide the base for the rise of a black middle class, private-sector change has been far slower, and led less by entrepreneurial drive than a rentier logic.

Papers (1998), Johannesburg on behalf of the ANC at the Adoption of South Africa's 1996 Constitution Bill, Cape Town (8 May 1996). 
Struggle movements in power face rising popular pressures for wealth redistribution and improvements in material well-being in the context of worsening problems of poverty, unemployment and inequality. These interface with residual unhappiness over economic participation, and land ownership. Twenty years after liberation, first in Zimbabwe, and now in South Africa, a new generation of political activists proclaim past transition agreements as "half-baked" and in some instances, as "sell-out" deals. These factors, coupled with incompetence and corruption in government in the context of cadre deployment policies, ${ }^{10}$ have constrained post-apartheid reconciliation drives, and contributed to rising levels of protest. Procedural justice based on a universal acquisition of primary rights has for many not translated into anticipated improvements in material well-being. National liberation movements have tended to be reluctant to relinquish power once achieved, and struggle increasingly to achieve social cohesion through democratic means.

What is justice and how is it to be served in the evolving reality of a burgeoning poor? In Rawlsian terms, under a "veil of ignorance" most people would commit to maximum levels of personal liberty. This makes for relatively easy drafting of Bills of Rights as they pertain to such issues as freedom of conscience, movement, assembly and protections from state oppression. However, as Sande $\left.\right|^{11}$ points out, there is no unity in principles to guide wealth creation and distribution in a society: should such measures be on the basis of birth into a particular identity group, contribution, need, capacity to compete in free markets, utilitarian concepts of what is good for the majority, or past injustices? Rawls's difference principle, in which inequality should be tolerated to the extent that it benefits the least advantaged in a society, is a political hard-sell because it is conceptually complicated, carrying the possibility that inequality might first increase if the lot of groups at the bottom is to improve.

In Zimbabwe, and now in South Africa, there are political groups rallying around the logic that land taken by conquest can be legitimately taken back by conquest. But of course, this does not deal with risks of declining food security in Africa. ${ }^{12}$ And while it is clear from whom land might be taken, what principles will guide the logic of who it should go to, and under what conditions? In Zimbabwe, President Mugabe, after opposing land grabs in the first instance, realised he could lose power if he did not switch. In South Africa, the African National Congress (ANC) and its opposition in the form of the Economic Freedom Fighters (EFF) ${ }^{13}$ find some unity in a desire to change the "willing buyer, willing seller" logic embodied in the Constitution to enable land expropriation without compensation. But is the route forward then nationalisation of land, or private ownership, or a mix, and under what conditions? The Zimbabwean experience forewarns the consequences of failure to effectively negotiate land issues, but they are complex. Some argue that white recalcitrance requires coercion to reverse past injustices -

10 Southall Liberation Movements in Power: Party and State in Southern Africa (2013) 134136, 347-348.

11 Sandel Justice: What's the Right Thing to Do? (2009) 156-157.

12 Luan, Cui and Ferrat "Historical Trends of Food Self-Sufficiency in Africa" 20135 Food Security 393-405.

13 Shivambu The Coming Revolution (2014) 131 132-134. 
an interactive mix threatening the wider negotiated reconciliation project initiated by the likes of Mandela and Tutu.

\section{THREE EXPERIENCES OF LAND TRANSFORMATION}

\section{Zimbabwe}

Zimbabwe's post-liberation land-redistribution process has reflected a collapse in governance rather than a considered strategy. In 1969, the Rhodesian government reserved for whites 48 per cent (15.5 million hectares(mha)) of the nation's land - in effect, 6000 individually owned farms and estates. The black population was awarded $16.4 \mathrm{mha}$, allocating 700000 black families to subsistence farming in "tribal trust" areas, with $1.4 \mathrm{mha}$ for 8500 small-scale black farmers. This was clearly inequitable from several perspectives. From a social-equity perspective, land was disproportionally distributed on the basis of race. Further, in denying black citizens economic opportunity, market principles were undermined, although there is a counter-argument that white political and economic dominance in an unregulated market would have seen all land accumulate quite quickly into white hands.

Under international pressure, and for reasons of pragmatism, the Patriotic Front agreed in the Lancaster House Agreement in 1979 to a market-based system of land redistribution. The reality at independence was that 6000 white farmers were central to the national economy. Under the new constitution, underused land could be compulsorily seized provided there was prompt and adequate compensation in foreign exchange. The United Kingdom (GBP75m) and the United States (US) (USD500m) agreed to finance land reform but, in 2000, stopped payment, citing corruption and constitutional abuses. ${ }^{14}$

ZANU-PF introduced a land policy intended to resettle 162000 families on redistributed land by 1984 . Resettlement was to occur through a smallhousehold track (5-6ha each with communal grazing); and a large commercial-farm track. By 1990, there were signs of increasing unrest over land, partially over its slow pace, but also perceived corruption as repossessed land found its way primarily into the hands of the families of a political elite. Panicked, the Commercial Farmers Union offered cooperation with government for resettlement onto unproductive farms but these efforts were seen as being too little. Zimbabwe's population had expanded rapidly from 7 million in 1982 to 10 million in 1992. Urbanisation surged without jobs growth, delivering a sharp rise in unemployed youth. A rising perception of elitist corruption, and fears of permanent marginalisation from the fruits of liberation, fueled an alliance between disgruntled war veterans and youth groups. The trade union movement bucked its socialist transmission-belt role, demanding jobs and higher wages and pushing Mr Tsvangirai forward as leader of a new opposition group, the Movement for Democratic Change (MDC). Then in 1992, the government started designating farms for

14 Meredith Robert Mugabe: Power, Plunder and Tyranny in Zimbabwe (2002) 119-121. 
acquisition, ignoring court orders and distributing them to government officials. As Mr Mugabe's crisis of credibility grew, he steadily shifted from opposing land grabs to backing them.

In 1990, ZANU-PF won 116 of the 119 seats up for election; and in 1995, 118 of the 120 seats but, from this point, there was rising protest action over unemployment and public disgust with government corruption. Things came to a head in 1997 when the US-funded War Victims Compensation Fund was exhausted months ahead of budget. The Chidyausiku Commission identified looting and fraudulent claims as the problem. A war veteran (of dubious credentials), Chenjerai Hunzvi, led a protest of about 50000 onto the streets threatening to take over white lands if pensions were not paid. In a political and economic bind, Mr Mugabe acceded to demands for land, free health care and education to the tune of an estimated USD4bn, precipitating an economic crisis. By 1999, about 20 per cent of white-owned farmland had been redistributed in the context of a rising economic crisis. When the government designated 1503 farms for redistribution (45 per cent of whiteowned commercial farmland), it evoked an international outcry, crashed the stock exchange, and saw international bodies either refuse further aid or assistance to the government, or require supervision of its implementation owing to previous abuses. The economic crisis prompted Mr Mugabe to send troops to the Democratic Republic of the Congo (DRC) in exchange for mining and timber rights and preferential trading rights in minerals. ${ }^{15}$

In 2000, over 50 per cent of voters in a referendum rejected government proposals: to limit presidents to two terms (Mugabe had stated he would start afresh to enable him to hold office to 2010); and to expropriate land without compensation for landless black people. Sensing himself at political risk, Mr Mugabe dropped all pretence of constitutionalism and reservations over land grabs. Promising war veterans land, he mobilised them to a campaign of terror against opposition groups and pushed through laws enabling land grabs. Farm occupations and expulsions of white farmers rose rapidly. Despite trying to write off the union leader, Mr Tsvangirai, as a white puppet, the MDC won 57 of the 120 seats up for election in 2000. The presidential election that followed in 2002 saw Mr Mugabe not only make heavy reference to the liberation struggle and issue bitter commentary on Western interference, but unleash a campaign of terror on opposition groups through war veterans groups and a youth militia, while actively supporting land grabs, and attacking judicial and press freedoms. ${ }^{16} \mathrm{Mr}$ Tsvangirai narrowly lost an election widely condemned as neither free nor fair.

By 2004, only 300 white farmers remained, with about 600000 labourers losing their work and support for their families ${ }^{17}-$ this, in the context of a wider collapse in the economy, in health and education services, huge unemployment giving rise to an estimated 3 million black Zimbabweans leaving the country, the elimination of an independent judiciary, and

\footnotetext{
Meredith Robert Mugabe: Power, Plunder and Tyranny in Zimbabwe (2002) 142-144.

Raftopoulos "Briefing: Zimbabwe's 2002 Presidential Election" 2002 African Affairs 101 413-426.

17 Hill What Happens After Mugabe? (2005) 18.
} 
widespread abuses by police. ${ }^{18}$ It is hard to determine the actual impact of Zimbabwe's land grabs, with some reports suggesting redistribution was more equitable than commonly understood and farming outputs higher,${ }^{19}$ but there can be little doubt they heralded a wider collapse in the national economy, were conducted unconstitutionally, and that Mr Mugabe's choices in the crisis favoured despotism over democracy.

\section{Namibia}

Namibia's land tenure systems differentiate between customary tenure on communal land (about 38 per cent of all land, all rural), and freehold in urban areas ( 1 per cent of land) and commercial farms (44 per cent of all land currently - almost all owned by about 5000 white farmers). Commercial farms were originally the preserve of whites in the pre-liberation period. National parks make up the remaining 17 per cent of all land. The population of about 2.1 million at the time of writing is evenly spread between communal land and freehold areas, but current rates of urbanisation could see 80 per cent in towns by 2030. Two areas of land reform occupy analysts: the transfer of land from white to black hands; and reforms surrounding tenure to enable faster development in communal areas. ${ }^{20}$

As with Zimbabwe and South Africa, Namibia's land-redistribution process is framed in its constitution by the "willing buyer, willing seller" principle, enabling the State to buy land at market value for redistribution to historically disadvantaged people. This, however, is a rarity. Instead, it seems the new political elite pushed to the front of the redistribution queue, and further that members of SWAPO's leadership are among those encroaching on the limited arable communal land available to the larger population. By 2000, only 341000 hectares had been purchased for redistribution to the landless. Most of those in communal areas remain dependent on food aid, and have received no support for farming projects. There are indications that government is reviewing the Constitution to amend clauses to allow involuntary land expropriation. ${ }^{21}$

In a National Land Conference held in 1991, Namibia framed its land policy: prohibiting foreign ownership of commercial land, though permitting leasing; banning multiple farm ownership; and pushing more underused commercial land into productive use. Then, to fast track the evolution of a black middle-class farming sector, an Affirmative Action Loan Scheme (AALS) was created in 1992 to assist communal farmers with enough stock to commercialise. In 1995, the Land Reform Act was passed, followed by the Communal Reform Act of 2002. Commercial farmers wanting to sell are

18 Hill What Happens After Mugabe? 2; Meredith The State of Africa: A History of Fifty Years of Independence (2005) 640-646.

19 Southall Liberation Movements in Power: Party and State in Southern Africa (2000) 238239.

20 Mendelsohn, Shixwameni and Nakamhela "An Overview of Communal Land Tenure in Namibia: Unlocking its Economic Potential" (2011) http://www.raison.com.na/Namibia\%20\%20Communal\%20land\%20and\%20its\%20economic\%20value.pdf (accessed 2018-01-13) 1-16.

21 Melber "No Land in Sight" (2017) https://www.dandc.eu/en/article/despite-independence1990-land-ownership-remains-unfairly-distributed-namibia (accessed 2019-05-17) 29. 
obliged to follow procedures offering the State first option at the price being offered. Government has been publicly supportive of the Zimbabwe process with various spokesmen proposing that transformation was too slow in Namibia, and threatening similar measures. However, action has been slower with the government anxious not to lose the support of foreign donors and wary of the consequences for food security; by 2009, only 11 per cent of commercial farmland had passed from white into black hands.

Namibia's political sovereignty in 1990 has not given rise to any significant change in the racial distribution of land. Inequalities in distribution, Melber ${ }^{23}$ argues, are the direct consequence of Germany's genocidal colonialism, but despite Germany's acknowledgement of atrocities against the Nama and Herero in 1902-4, it is toning down use of the term genocide and is against the idea of funding land redistribution as a form of reparatory compensation.

People living in communal areas are largely poor and dependent not on incomes generated by farming, but on non-farming activities such as pensions, businesses, wages and remittances; and able-bodied men have emigrated to urban areas to work. Mendelsohn et $a^{24}$ argue that reforms in tenure systems in communal areas would enable opportunities for economic development that would benefit historically disadvantaged groups. Apart from the need for training and support systems to raise farm productivity, investment incentives are limited by complex procedures for acquiring land for commercial uses; and by land rights not being tradable or suitable for collateral to generate capital. As indicated above, commonage areas have tended to be purloined by elites through unilateral and uncontrolled privatisation using fencing, rather than by residents in communal areas, who have instead seen access to such areas decrease. While the transfer of land from whites to historically disadvantaged individuals and groups occupies so much attention, Mendelsohn et $a f^{25}$ argue that greater attention is required to enable the poor and disempowered living in communal areas. Such steps would assist the national economy by turning the third of national land currently economically dead into functional capital, bringing more of the historically disadvantaged into the modern economy and giving them access to property ownership, and incentivising the development of communal land.

A follow-up conference on land reform was planned for 2016, postponed by the government to September 2017, and then postponed again with President Geingob stating that more time was needed to consult stakeholders in light of the complexity of the matter. In the build-up to the conference, shortcomings in redistribution planning and action have given rise to tensions between government and commercial farmers with each producing different data and blaming one another for any shortcomings in progress.

Southall Liberation Movements in Power: Party and State in Southern Africa 239-241.

Melber https://www.dandc.eu/en/article/despite-independence-1990-land-ownershipremains-unfairly-distributed-namibia.

24 Mendelsohn et al http://www.raison.com.na/Namibia\%20-\%20Communal\%20land\%20and\% 20its\%20economic\%20value.pdf 11-15.

25 Ibid. 


\section{South Africa}

South Africa was the last of Africa's nations to achieve release from white minority rule. Under the Land Acts (1913 and 1937), the white settler population had passed laws designating 87 per cent of the land to themselves, restricting black ownership to 13 per cent. When the apartheid period ended, 60000 white farmers owned 87 per cent of the land.

The Freedom Charter of 1955 acted as a beacon for the ANC during the liberation struggle, and a key element in mobilisation against the apartheid regime was the promise of land reform. But, as the Zimbabwe experience reveals, it is sometimes much easier to identify an injustice than to remedy it. And the land issue was too complicated for the negotiators of South Africa's peace deal in 1994 to deal with in detail. In conformity with the southern African pattern, the drafters of South Africa's interim (1994) and then final Constitution (1996) settled on a process defined by the centrality of the "willing buyer, willing seller" principle. They made provision for compulsory land purchase conditional on "just and equitable" terms, these to be decided on a case-by-case basis by the courts ... and then left it to government and the courts to eke out a system of justice.

To manage the process of land reform, South Africa's democratic government instituted a three-track policy distinguishing between tenure reform (to address lack of tenure of farmworkers and those on communal land), land restitution (to compensate victims of forced removals following the 1913 Land Act either with land or cash); and land redistribution (to enable previously disadvantaged citizens to apply for grants to buy land for farming).

Tenure reform is an ideal running counter to reality. Since 1993, agricultural employment has fallen from over a million to 849792 , of whom only about half enjoy full-time employment. Tightening regulations and legislating higher wages has served to increase capital substitution and is likely to see further jobs decline. Land restitution has enjoyed some success, but the redistribution project has fallen dismally short of the aspirations of many. As regards restitution, 77622 claims had been settled by 2014, benefitting 371191 families, with 3078 mha of land approved for resettlement. In 1994, the government declared an objective of redistributing 30 per cent of land in white hands to black ownership by 1999 but, in a series of steps, shifted the deadline to 2025 . Some estimate only 7 per cent of land has been transferred from white to black hands. But the very question of land ownership begs others: who really owns the land? what land matters - and to whom? who really wants land and for what purposes? and what criteria should guide redistribution? To put in a claim, a person must have been dispossessed of a right to property after 19 June 1913, and must be a community or have been part of a community that was dispossessed. Claims had to be lodged before the end of June 2019.

The issue of who owns the land in South Africa has been difficult to ascertain, with interest groups framing available data strategically. The land audit report by the government indicated $114.2 \mathrm{mha}$ of land was registered at the deeds office. Ownership was distributed as follows: government $17.1 \mathrm{mha}$; trusts $29.3 \mathrm{mha}$; companies $23.1 \mathrm{mha}$; white individuals $26.6 \mathrm{mha}$; 
black individuals 1.3mha; coloured individuals $5.2 \mathrm{mha}$; and Indian individuals $2 \mathrm{mha} .{ }^{26}$ However, there is an argument that the above figures misrepresent actual racial distribution and control of the land; that state land is essentially "black owned" and can be distributed at the discretion of the State; and that some trusts also place land under black control. King Goodwill Zwelithini is the sole trustee on behalf of his people of the Ingonyama Trust, which includes almost 30 per cent of KwaZulu-Natal. Both the leader of the ANC and the EFF have assured the King the Trust is not under threat, and the DA has given support to it as well. One estimate puts state ownership of land at 25 per cent (and thus in the discretion of the State for redistribution purposes), while black farmers own 20 per cent; coloured and Indian farmers 10 per cent; and whites 45 per cent. According to AgriSA (2017) though, 73.3 per cent of agricultural land is currently owned by whites with the remaining 26.7 per cent in the hands of government and previously disadvantaged groups - up from 14.9 per cent in 1994.

About a third of white farmers $(20000)$ are concentrated in the 13 per cent of land that is actually richly arable, and account for 80 per cent of commercial agricultural output. This is the land that really matters from a farming-food-security perspective. Many small farms are marginal and may be difficult to turn into profitable enterprises. Land claimants may not have the skills, capital or the desire to invest their efforts into farming. According to government, many redistributed farms lie fallow or fail, and their new owners may seek to sell them. It is estimated by the government that up to 30 per cent of land already redistributed has found its way back into white hands. According to the Department of Rural Development and Land Reform, $17.54 \mathrm{mha}$ of farmland has been transferred in various ways from white ownership since 1994. ${ }^{27}$ Table 1 reflects an estimate of land transfers across provinces. The Western Cape had a very low presence of Africans at the time of colonisation so its figures are not surprising. The higher figures for provinces to the north-east reflect a much heavier presence of the black population at that time and stronger historical claims to land under current law.

Table 1: Shifts in black-owned land by province

\begin{tabular}{|l|l|l|}
\hline Land owned by blacks by province & $\mathbf{1 9 9 4}(\%)$ & $\mathbf{2 0 1 6}(\%)$ \\
\hline Western Cape & 0 & 4.9 \\
\hline Eastern Cape & 28 & 48.3 \\
\hline Northern Cape & 0 & 6.4 \\
\hline Kwazulu-Natal & 45.4 & 73.5 \\
\hline Mpumalanga & 10.6 & 39.7 \\
\hline Limpopo & 38.6 & 52 \\
\hline Gauteng & 0 & 39.1 \\
\hline Free State & 1.6 & 7.9 \\
\hline North West & 34.5 & 45.3 \\
\hline
\end{tabular}

Source: Grootes 2019, in turn sourced from Landbouweekblad; Agri SA

26 Grootes "Making EWC Work" (Jan 31-Feb 6 2019) Financial Mail 20.

27 Ibid. 
If one accepts that land in white hands was acquired illegitimately and should be returned, the question is to whom, and if the consequence of a poorly guided redistribution is a collapse in food security, who will be accountable? At the time of writing, the EFF, based on its admiration for the ZANU-PF approach to land redistribution in Zimbabwe, is espousing a policy of unlawful land occupations and land seizure without compensation. Its logic is simple: the land was stolen from black people who were on it earlier, and they should not have to pay for it to be returned. Its plan is that all land should be state-owned and leased out on the basis of "productive use".

There is a rising intensity in the debate, and the stakes are very high indeed. No further collapse of southern Africa's food security can be reasonably contemplated. Already, Zimbabwe carries an estimated 80 per cent level of unemployment and South Africa has absorbed an estimated 3 million of its economic refugees. South Africa cannot afford a similar degree of error in its search for workable justice on the land redistribution front.

\section{JUSTICE IN LAND DISTRIBUTION: THE PRESSURES FOR LAND REFORM}

There is frustration among analysts on issues of land reform. The recognition of past injustices that require redress is one shared by political parties in South Africa but a review of their 2019 election manifestos reflects how differently they think on the matter. Election campaigning easily polarises parties and will raise risks for the economy.

At the end of 2017, Mr Mugabe was removed from Zimbabwe's presidential office in a coup contrived as a resignation. On assuming office, Mr Mnangagwa first appointed military leaders to his cabinet (revealing its continued influence), but then lost little time in calling for the return of white farmers and in removing a Mugabe ally from a recent farm takeover and returning its previous (white) owner along with his workers (signaling a softening on official land ownership and management). Mr Mugabe apparently violated his own edicts not to use white managers on farms, and it is reported that his 14 illegally acquired farms will be reduced to one. Mr Mnangagwa has publicly recognised the need to attract foreign investment and to end corruption, the importance of the agricultural sector to the Zimbabwean economy and the need to return it to previous levels of productivity. However, no clear policy has emerged on these issues. It is hard to imagine a wholesale return of land to white farmers, but what principles will guide the return of land? Will there be conditions along racial lines? Will the land be nationalised and leased out? Will there be requirements that all farms be productively and profitably worked? Perhaps the most important signal in all this is that ZANU-PF has recognised the failings of its land-grab policy. However deep the sense of injustice over the land and however pressing popular protest might be, a "take back the land in conquest" approach is not viable if it collapses food production and impacts negatively on the economy. Currently, under pressure it seems from international investors and loan agencies, the Zimbabwean government has announced that since 2009 it has paid USD64.4 million in compensation to 93 white farmers who lost their farms - not in respect of the land per se but 
in respect of immovable value-adding infrastructural additions. A further amount of USD17 million is to be distributed among 1000 of 3500 claimants in the 2019 budget. There is contention over whether any payment should be made at all, the adequacy of the compensation, whether the Commercial Farmers Union (CFU) is representative of all affected farmers, sources of funding and distributive decision-making, with the CFU stating it will go primarily to elderly farmers in financial distress. ${ }^{28}$

At the same time as Zimbabwe appears to be reconsidering its approach, the ANC in government in South Africa is facing some of the same pressures its neighbour experienced twenty years previously: rapid population growth, slow economic growth, urbanisation pressures, high unemployment (especially among township youth), and falling popular support. A re-evaluation of the ANC is underway with sections of the youth arguing the revolution has failed, suggesting the ANC sold out on economic reform in an unholy pact with white capital in 1994. The party has been compromised by the corruption and poor delivery of its cadres in government It lost control of several major cities in local elections in 2016 . Voters really have a choice between two existing alternatives: the EFF proposing an economic revolution along Marxist-Fanonist lines including a nationalisation of land and expropriation without compensation; and the Democratic Alliance (DA) holding to a liberal democratic line with an economy founded on market principles. The ANC clearly sees the major threat to come from the former. While it has voted in Mr Ramaphosa, a business-oriented multi-millionaire as president of the party, his victory was a narrow one, and the 2017 ANC Conference also supported an approach of "radical economic transformation", pushing for a change in the Constitution to enable the expropriation of land without compensation. In Namibia, the government, sensing rising tensions, has avoided open debate, apparently to assemble a solid database before entering public discussion.

Once in office, President Ramaphosa initiated a process of public consultation on how to make more explicit the language of the Constitution that allowed for expropriation of land without compensation in the public interest. In addition, an explorative state expropriation of a farm in Limpopo was been undertaken to test the legislative and economic waters, as it were. The government took the step after talks over acquisition broke down, with the white farmers demanding R200 million for the game farm but being offered only R20 million by government. It is being opposed in court. The chairman of the Land Bank warned that land seizures could put it in financial jeopardy. In the context of rumours that about 200 farms have been earmarked for expropriation, a record number of farms have been put up for sale, but of course the market has disappeared with the uncertainty. ${ }^{29}$ At the end of 2018, the Expropriation Bill was gazetted. It contained no mention of nationalisation; the Bill referred solely to land, and five types of land were

28 Corcoran "White Farmers in Zimbabwe get \$64m in State Compensation" (May 2019) https://www.irishtimes.com/news/world/africa/white-farmers-in-zimbabwe-get-64m-in-statecompensation-1.3896055 (accessed 2019-05-20) 1.

29 Pearson-Jones "South Africa's President Declares It Is Time to 'Correct a Past Wrong' by Grabbing Land From White Farmers as $£ 10 m$ Hunting Lodge Is Targeted for Seizure by the State" (2018) http://www.dailymail.co.uk/news/article-6080071/South-Africas-threatens-land -grab-against-white-farmers.html (accessed 2018-08-20) 1. 
identified for expropriation purposes: that used by a labour tenant; that held for purely speculative reasons; land owned by a state-owned entity; land abandoned by its owner; and land that is worth less than any state subsidies it might attract. In its 2019 election manifesto, the ANC promised to support amendment of section 25 of the Constitution in a manner that promotes economic development, agricultural production and food security. As Grootes $^{30}$ points out, this is not a land-grab approach.

\section{SO, WHAT TO DO - AND WHAT PRINCIPLES OF JUSTICE HAVE RELEVANCE FOR FUTURE ACTION?}

Land remains a matter of unresolved conflict across the southern-African countries under review here. It is an issue that evokes intense emotions, and as a consequence sees expression in extreme demands, angry positioning, and zero-sum bargaining approaches, if negotiation happens at all. The stakes are extraordinarily high and way beyond the interests of those currently directly involved: how tensions over land are resolved has consequences for the national economy, food security and the political stability of the region.

The Zimbabwean experience reflects the consequences of unconstitutional, violent land grabs as a means of redistribution, but also the consequences of a failure to negotiate a change process effectively. The ANC in South Africa, and SWAPO in Namibia, face similar pressures to those that ZANU-PF faced under Mr Mugabe in the period before the land grabs took place. Attention should be given to the deeper identity-based meaning that land has across population groups, ${ }^{31}$ but in immediate practical terms, if change is to be negotiated, the issues centre around who should be involved (which stakeholders), on what aspects of the process, which issues should be prioritized and in what order, and the mechanisms of any negotiations?

The capitalist-communist debate remains as live in South Africa as its adherence to racial categories. The problem with ideologies is that their advocates tend to participate in debates with positions. The desire for ideological coherence can override contrary evidence, and distort problemdefinition and debate into pre-determined answers. If parties hold to simplistic hardline positions on market principles based on property ownership, or on nationalisation through expropriation without compensation, it may close down a creative mix of approaches.

Grootes (Jan 31-Feb 6 2019) Financial Mail 2022.

31 Bradshaw, Haines and Anstey "Land and Reconciliation" in Rosoux and Anstey (eds) Negotiating Reconciliation in Peacemaking: Quandaries of Relationship Building (2017) 231-250. 


\section{A POWER-BASED APPROACH TO TAKE BACK WHAT WAS UNJUSTLY TAKEN: SIMPLE RESTORATIVE JUSTICE}

In its 2019 election manifesto, the EFF promises: immediate amendment of the Constitution to expropriate land without compensation; nationalisation of all land for equal redistribution to all under progressive state custodianship; redistribution using demographic proportionality, including 50 per cent to be controlled by women and youth; the abolition of foreign land ownership; the establishment of a People's Land Council to manage distribution to those who need land for residential and productive purposes and a land ombudsman to protect against abuses by the State and mining companies; and the establishment of a new People's Land Court to expedite redistribution. Further, it will abolish rentals of residential land; not abolish the rights of traditional leaders; and nationalise all game reserves.

The actions of Zimbabwe's land-grabbers and the logic of the call by the EFF in South Africa for expropriation of land in white hands without compensation is rooted in the logic: "the land was taken from us in conquest, it can be legitimately taken back, if necessary in conquest. Why pay for something that was stolen from us?" Advocates of this approach would probably see little value in the plans of some white farming communities, not to give up ownership of the land, but to offer workers a share of the crops or livestock on it. The core issue from this perspective is ownership rather than returns.

So why is a simple "take the land back" approach not feasible, or necessarily just? One obvious reason is that the consequence of such action would probably be catastrophic for food production and the economy. However unjustly white farmers are perceived to have acquired their farms, they are current possessors of the key competencies necessary to make those farms functional for the benefit not only of themselves, but for the nation as a whole. In short, while their historical acquisition of farms may have been based on their membership of an identity group, many have since cemented their power through possession of key skills. Beyond this, there are difficulties in establishing the legitimacy of claims. Many farmers, particularly in the Western Cape, argue there were very few or no people in the areas where they built their farms, and many white farmers can claim that their forefathers literally created commercially viable farms where there was "just bush before".

The EFF's proposals constitute a broad-brush understanding that "whites took the land from blacks across the region", and it should therefore be returned on a large-scale ascriptive basis, eliminating problems of claim legitimacy through total nationalisation. But then the State must still deal with questions of land distribution and productivity in a use, if not ownership, sense. There would still be claims to priority access to land and support from the State, and the risk is that land would eventually simply be awarded on the basis of clan or class or political party loyalties rather than farming competence. 
The EFF offers no real answers to some of the tough questions of who should farm the land. Its nationalise-all-land approach sidelines questions of claimants' rights to land, but it does not deal with issues of state competence, or the nuts and bolts of decision-making about land distribution.

Restorative justice, of course, might not involve nationalisation, but the alternative presents claimants with problems of asserting a claim, and those distributing land with decision-making puzzles on the legitimacy of claims. Does it matter whether claimants were actually farming the land in question, just passing through in a nomadic farming cycle, or just resident without farming for a period in the past? Then, who should receive the land and under what principles: a "community"; a chief or lineage of a chief; or a new local authority on behalf of a community?

\section{A MARKET-BASED JUSTICE APPROACH (WILLING BUYER, WILLING SELLER)}

At present, the constitutions of Namibia and South Africa are based on the values and principles of market-driven economies within liberal democracies. The "willing buyer, willing seller" approach is founded on principles of property rights, freedom of economic opportunity and a belief that competitive economies are key to economic growth and wider societal wellbeing. Adherents to this approach make several important points. Nations whose development has been founded on the protection of individual property rights, free commercial activity and the rule of law have far stronger economic track records than those based on collective or communal logics. They point to the failed and often-disastrous experiments in communal farming in the last century of Russia, China and Venezuela, and in Africa to those of Tanzania and Zimbabwe. Beyond this, there is the argument that the constitutions of Zimbabwe, Namibia and South Africa reflect the essence of the deals achieved to enable political transition and that these should be honoured. Violation of this approach may carry heavy consequences in terms of the wider rule of law, but importantly also for food security, the financial sector to which farmers are indebted, and investor confidence across all sectors of the economy.

South Africa's opposition party, the DA, adheres perhaps most closely to a market-based logic of land reform and opposes the ANC's proposals for constitutional reform as a tactic of political expedience. In its 2019 election manifesto, it argues that expropriation without compensation will turn land reform into a zero-sum game and is instead seeking a win-win approach. Redress is needed, but it must be sought by: working with all stakeholders (including traditional leaders and communities) to give title deeds to those who live on communal land; releasing unused government land for residential and farming needs; giving title deeds to urban homeowners to enable inheritance; creating voluntary incentivised partnerships with farmers to enable farmworkers to own shares in the farms they work on; institutional support for land-reform beneficiaries to ensure their success; and speedy settlement of land claims. 


\section{A COMMUNAL-JUSTICE APPROACH}

The restorative justice-through-nationalisation proposals of the EFF also reflect a communal justice thinking. Critics of the "willing buyer, willing seller" approach see it as simply ignoring past injustices regarding the acquisition of land, and as contrived to entrench the status quo of land ownership and economic opportunity in the agricultural sector, and as an imposition of Western value systems alien to African society. A simple free-market approach would probably see a widening of the gap between the haves and the have-nots; land and capital accumulation would remain in the hands of a few and would not be responsive to political pressures by previously disadvantaged groups (that is, will inevitably lead to political and economic instability). A wide ideological divide exists between advocates of market principles and the Marxist-Fanonist frame from which the EFF approaches the land question. From a communal perspective, no individual should own large tracts of land that allow exploitation or marginalisation of others; land is there for the good of all; ownership in a market system facilitates exploitation and puts individual greed above national needs and interests; the State, on behalf of a people, should own all land and manage its use. Various options exist including state-managed farms; state or small private collective farming through co-operatives; and reluctantly sometimes, long-term leases for productive individuals.

While the EFF proposes that land be distributed on the basis of productive use, the mechanisms for such management are not clear. What is clear is that the process of land management will shift to the State, and this usually implies decision-making by a political elite. Even well-resourced governments struggle to deliver core public goods efficiently, so it is difficult to imagine that South Africa will have the expertise to manage a national agricultural project effectively - along with other proposed nationalisation projects in mining and banking. Beyond this, in state projects, individuals lose their capacity to offer their land as security in raising credit for farm development, thus constraining capacity, incentives and direct accountability for any envisaged projects. And while it may be clear from whom land might be removed, who will receive it, using what criteria, following what procedures and how will performance be evaluated for continued use? Only 11 per cent of land has been transferred in Namibia but the indications are that a political elite has jumped the queue to become major beneficiaries of opportunity and has led a process encroaching on communal land to the disadvantage of the poor. In Zimbabwe, much land has apparently found its way into the hands of a political elite rather than those seeking to make a living from farming. Disguised ownership rather than productive use seems to have been a key motivator.

If all land is nationalised and then redistributed for use by the State, how will this be managed? If "productive use" is to be the criterion what measures will be used for this purpose, and over what periods of time? If land is not used productively, how will incumbents be removed and replaced? What will prevent a political elite from simply taking control of redistribution for their own ends at the cost of the wider population and from using state resources to protect their control of sections of the land? 


\section{COMPENSATION PAYOUTS - A REPARATIVE- JUSTICE APPROACH?}

Even hard free-marketers recognise the reality of past injustices and the need for political stability; they accept the morality of some sort of redress and the need to rapidly expand a black middle class, with farming as one sector for attention. The restitution element of the South African land-reform strategy responds to this reality and is indeed the mechanism most used in its system so far. But while once-off payments may clear the consciences of past and current beneficiaries of inequitable systems, and the immediate desires for cash on the part of those previously disadvantaged, they will not necessarily see claimants sustainably satisfied or economically empowered. This approach recognises past injustices regarding property rights and land use but does not seek to tamper with current ownership or production systems. Rather victims and their offspring are offered a cash payout or alternative land opportunities as compensation for past losses. The problem is that such sums, while "letting current owners of land off the hook", may not lead to sustainable financial security for recipients. It may be a temporary palliative but have little longer-term impact on poverty, inequality and political instability or renewed demands for land by future generations arguing their fathers had no right to settle for payouts, or that they did so in contexts of clear duress.

\section{AN AFFIRMATIVE-ACTION APPROACH}

Believers in the values of competition also recognise that it might be unfair to expect previously disadvantaged individuals to be able to compete fairly with those with lives of privilege. All the countries under discussion here have implemented affirmative-action policies in the form of black-economicempowerment schemes, support for training, access to finance for education or to undertake commercial farming. However, when the stakes are framed in terms of a nation's food security, opportunity must translate into outputs. South Africa's President is pushing for an investigation into why redistributed farms are lying fallow. The risk in granting claimants land is that they will not, or cannot, turn them into productive farms. Affirmative action then must become far more than a grant to acquire land. For example, the Sundays River Citrus Co-op in the Eastern Cape offers new farmers a full array of support services to enable success. They provide the expertise of agronomists and cooled warehousing, offer assistance with shipping to export destinations, locate offshore markets and negotiate terms with buyers. Meaningful affirmative action thus requires long-term holistic support, rather than a one-off payment if it is to have prospects of success, which is in turn dependent on a committed cadre of black farmers and farming communities willing to invest energy in their development. As indicated above, farmers might also offer a share of crops and livestock on their farms and actively promote farming skills among workers on farms. But for advocates of nationalisation programmes for whom ownership is the core grievance, this is unlikely to be sufficient.

Of course, a claimant to land who benefits from affirmative action might still argue that he or she has a right to do what he or she wishes with land 
legitimately owned, including letting it lie fallow, and here questions must be answered as to whether boundaries should be placed on possession of land that is not farmed - not an easy one for advocates of market economies.

\section{DOING WHAT IS GOOD FOR THE MAJORITY: UTILITARIAN JUSTICE}

This brings us to a discussion on concepts of utilitarian logic: what produces best outcomes for the majority? Here, unfortunately, all the risks of ideological debate, and problems of determining what is really in the interests of the majority are re-entered. Is it that the sense of injustice over land distribution is so deep that only repossession will make the majority happy? What if this sees a collapse in food security and impacts negatively on the economy? Should one start therefore on a premise that food security is paramount - at its most basic, a population cannot be happy if it is not fed?

Liberal democrats will argue that food security is best served under current conditions of property ownership together with affirmative action and reparative measures to deal with injustices of the past. The MarxistFanonists will argue that the only route to majority happiness is elimination of property ownership - nationalisation and regulated distribution based on productive use. But, as we have seen, this leads to other dilemmas of management, and of course what if productive-use capacity remains largely with experienced (white) farmers?

Mr Ramaphosa has promised to initiate and personally lead an enquiry into the causes of failed redistribution projects and how to overcome the problems. Enoch Godongwana, the outgoing ANC head of economic policy, was supported by Mr Ramaphosa when he proposed that reforms should not negatively affect either food security or the financial sector to which farmers are heavily indebted. Mr Ramaphosa stated that land ownership would occur without compensation "where appropriate" and in such a way that agricultural production is increased.

\section{A SOCIAL-JUSTICE APPROACH}

Advocates of this approach argue in terms of Rawls's difference principle ${ }^{33}$ that is, that inequality is acceptable only to the point that it benefits the least advantaged in a society. This has a conceptual cogence but how would it be implemented? Socialists would see the risk of rising inequality being condoned on the basis that the existence of a few, very wealthy landowners are somehow good for the majority in that they provide work and wages for many. Current landowners argue that they already benefit societies through taxation based on wealth creation, and through efficient food production for

32 Mailovich "Ramaphosa Calls For Agriculture Revolution in Land Reform" (2018) https://www.businesslive.co.za/bd/national/2018-01-12-ramaphosa--calls-for-agriculturerevolution-in-land-reform/ (accessed 2018-01-13).

33 Rawls A Theory of Justice (1973) 75-83. 
the benefit of the wider population. In this polarity, the nuances of Rawlsian justice may be lost.

\section{THE SEARCH FOR A MIX OF JUSTICE PRINCIPLES SUITABLE FOR PURPOSES OF REGULATING TENSIONS OVER LAND ISSUES - CAN PRAGMATISM PREVAIL?}

There are sufficient approaches to justice for advocates of both the status quo and for change to find purchase in the scrum over land issues. Past liberation movements (now in government) face dilemmas in responding to pressures for land transformation. Their constituencies are holding them to account for transformation goals they mobilised around, but which were set in the 1950s rather than in the political and economic realities of the twentyfirst century. The risks of simply appeasing popular pressure are evident in the Zimbabwe experience but, of course, not all parties involved see this as a risk. Activists for revolutionary change see value in escalating conflicts to the point of system breakdown to enable the introduction of completely new systems of governance and economic management. They accept the costs of breakdown in the search to rebuild a dignity for people seen as long exploited under the unjust policies of past regimes. So, the first question to be asked is the degree to which stakeholders across the board see benefit in seeking a negotiated way forward, or whether the greater benefit is in escalating conflicts to a point where opportunities for radical change are created.

The short overview of policies and the problems of transformation above suggests that although nations may have fallen short in their land-reform objectives, the drafters of transition deals and constitutions and early policy in Zimbabwe, Namibia and South Africa recognised the complexity of the issues and sought a pragmatic approach to the issue of land transformation. South Africa has a three-track approach, attending to needs for tenure security, restitution for victims of forced removals, and land redistribution for historically disadvantaged citizens to acquire grants for the purchase of land for farming. Namibia has espoused a policy of securing protections for farm ownership by citizens, and affirmative-action support for those historically disadvantaged under past governments to secure farms for commercial purposes.

But these policies have seen only slow change. Sensible negotiated change should start with an understanding of the reasons for this, as suggested by Mr Ramaphosa. There is an argument that the constitutional protection of the rights of property owners and also requiring compensation for land expropriation in Zimbabwe, Namibia and South Africa has seen current owners deliberately inflate prices to obstruct implementation of this legal space. Farmers counter by arguing that the size of capital investment, and development of the land, and lost future earnings should be costed into any such transactions. This of course opens up a wide range of economic considerations but a more fundamental question is raised: how many such transactional opportunities have in fact been obstructed in this manner? And how many black farmers are in reality indicating a desire for land that is 
under consideration? Corrigan ${ }^{34}$ suggests that the excitement generated by the politics of land reform obscures the reality of farming as "hard, risky and uncertain work", requiring technical, managerial and market expertise for relatively modest returns. So, is the energy for land transformation really one created by politicians banging ideological drums to mobilise votes from the poor and marginalised, or is it based on a genuine hunger among black farmers to access, and make productive, land currently in white hands? Is the energy sourced more in the need to redress an historical injustice expressed through the disproportionate ownership of land by white South Africans, or pressure created by real black South African farmers for land they cannot acquire owing to historical disadvantage? This does not imply that the poor and marginalised do not have genuine needs that demand attention, but is it moral to mobilise them around land repossession if they have no "productive use" aspirations?

Within its manifesto for revolutionary change in South Africa, the EFF advocates an approach in which all land will be nationalised and then leased out based on "productive use". The ANC supports transformative measures, but only those that do not endanger the nation's food security or have a negative effect on the economy. So too, the successive delays by the Namibian government in convening a land conference indicate caution over any changes that might have negative consequences in terms of investor confidence and farm productivity. So, important questions must attend the meaning and measurement of "productive use", accompanied by a discovery of what people really want. The statistics available indicate a much higher desire for financial compensation than a return of land in South Africa in restitution cases, as well as a failure of farms acquired through redistribution or a preference to turn them into cash returns through sales back to white farmers. Why is this? How many black South Africans really want land for farming (that is, productive) purposes? And of these, how many are competent to run commercially successful farms? How many, with the right levels of institutional support, could quickly learn to run commercially successful farms? And who should provide such support? A recent highlevel panel on land-reform law led by past president Motlanthe noted that the need to pay compensation had not in fact been the major hindrance to change. To be sure, a lack of farming expertise had been aggravated by drought conditions in recent years but the real problems, he concluded, lay rather in a lack of political will, diversion of land-reform budgets to elites, corruption, and a lack of training and support. ${ }^{35}$

The logical place to start such important negotiations, complicated by diverse approaches to justice, is with data rather than ideology. Beyond this, if destructive confrontation is to be avoided, parties should be thinking in terms of accommodating one another in a multi-track approach to the issues, rather than pushing one-size-fits-all approaches; desires for restitution and reclamation must be attended to, and the need for focused affirmative action and improved institutional support must be addressed. Unfortunately, the

34 Corrigan "Ramaphosa, Here's the Real Reason Why Land Reform Has Been an Epic Fail" (2018) http://www.huffingtonpost.co.za/terence-corrigan/cyril-ramaphosa-and-the-garden-ofeden-understanding-the-real-lessons_a_23329449/(blog accessed 2018-01-13) 1 .

35 Corrigan http://www.huffingtonpost.co.za/terence-corrigan/cyril-ramaphosa-and-the-gardenof-eden-understanding-the-real-lessons_a_23329449/ 1. 
current debate has been characterised by an increasingly shrill political discourse rather than drawing on detailed public information. Farms take many forms, with much variation in their complexity as to technological and managerial requirements, and profitability. There is merit in both, of course, but a difference exists between a desire for land for farming purposes, and a desire for land based on a sense of entitlement owing to past injustices or demographic proportionality or identity group membership.

Then, there are differences in ideologically driven preferred outcomes whether the protection of private property under a capitalist logic, collectivist thinking as an approach to farming, state ownership and commandist thinking about land allocation and use, or determination of the legitimacy of claims to ownership based on past injustices of dispossession or length of ownership and depth of investment in building a farm. Is there any reason why all these ideologies and principles of claim might not find accommodation in a negotiated land dispensation? Is it not possible within the range of land forms and farming systems to set up experimental projects of transformation, individual and collective, to evaluate which contributes most effectively to food security while responding to aspirations for land ownership and redress?

\section{IS IT POSSIBLE TO DEVELOP A SET OF CORE GUIDING PRINCIPLES?}

A good database would be useful, but so would a set of core shared principles. Is it possible for the range of stakeholders involved in the land debate to develop some core shared principles or objectives that go beyond simply their own claims to guide their negotiations? For instance, is it possible for all stakeholders to agree: (1) that an historical injustice underlies tensions over land distribution; (2) that for reasons of national reconciliation, political stability, and moral redress, remediation and change in the frame of land ownership and management is not only reasonable, but imperative; (3) that it is important to accelerate change but that it be managed in terms of the Constitution; (4) that there is acceptance that change should not endanger food security, the financial sector or wider investment confidence in the economy? A review of political parties' 2019 election manifestos indicates that the DA and the ANC in particular accept that no one principle of justice can be used to come to a conclusion on the land problem. It will require negotiation among many stakeholders holding divergent views on justice if progress is to be made in a way that secures food security and the wider economy.

The ANC sees land reform as being about redressing historical injustices and dispossession of the black majority, unlocking growth opportunities, and promoting socio-economic transformation. Its programme promises a sustainable but radical way to address the land question, using land reform to build productive assets for the nation's people, unlocking agricultural productivity, securing food security and addressing the persisting reality of apartheid spatial separation. Its reforms support constitutional amendment to define conditions allowing expropriation without compensation in a manner that promotes economic development, agricultural production and food security. The ANC's programme promises to speed up resolution of 
outstanding land restitution claims; work with established agribusiness to increase export earnings; develop greater support for emerging and smallscale farmers; invest in research and technology to raise performance of the sector; work on mitigating effects of climate change; address the dominance of big players that marginalises small-scale farmers, and assist such small actors with access to resources and markets; and promote access to farming by women and youth, accelerate land tenure reforms and the issue of title deeds.

\section{PARTICIPATION QUESTIONS}

Finally, issues of participation must be addressed. Is land reform to be a process largely assumed by political representatives or will it be guided through extensive consultation across sectors in a society, and if so, how will this be managed? Which groups should be at a negotiation table or policy conference? Who will represent "wannabe farmers"?

Countries in the south of Africa had the longest histories of colonial occupation and, as a consequence, the most difficult liberation processes, but they also saw liberation movements in government acquire the most developed infrastructures. Political liberation was achieved following a bitter civil war in Zimbabwe, and after a prolonged struggle and international pressure on South Africa and what is now Namibia. In each instance, political freedom has not met the hopes and aspirations of the indigenous black population. In each case, land has emerged as a central issue in the debate about economic transformation. In all cases here, the newly liberated states emerged with constitutions reflecting the market-based "willing buyer, willing seller" principle, but allowing state expropriation with prompt and reasonable compensation. In all cases, and interestingly about twenty years after liberation, changes in political and economic conditions saw liberation movements in power accused of having been too slow or even of betraying the revolutionary struggle, and the issue of land moved centre-stage in the tensions. In each, the mix was rapid population growth with concomitant urbanisation pressures; economic growth rates too slow to ward off rising unemployment especially among youth; and rising inequality despite the emergence of a black ruling class. Within the inequality mix, economies have continued to be dominated by white business interests and land remained largely in white hands. Under pressure from the streets and in the face of falling political support, ZANU-PF in Zimbabwe, the ANC in South Africa and, to some extent, SWAPO in Namibia face rising demands on the emotive issue of land - in each case still largely in white hands.

The urgency of land issues is now clear. Resolution of the issues is unlikely to be easily achieved, and radical land-grab approaches along Zimbabwean lines may prove to have unbearable consequences. But if such radicalism is to be avoided, then stakeholders must do more to make reform workable. No one ideology of justice will deliver on all the desires for land, farming productivity, food security, reparation, and redress of past injustices. Only a multi-track, multi-layered system of response offers prospects of success - and it will probably be in the form of regulated, rather than resolved, conflict - a continuing work of negotiation in progress. 